\title{
AN ANALYSIS OF SUBJECT-VERB AGREEMENT ERRORS ON STUDENTS' WRITING
}

\author{
Siti Nurjanah \\ Sebelas Maret University \\ khasanahnurjanah@gmail.com
}

\begin{abstract}
This study is aimed to examine the written subject and verb agreement errors made by the students of management department studying in Universitas Muhammadiyah Yogyakarta when they were writing their paragraphs in present tense. Error analysis technique was carried out in this research in order to find the errors faced by the students in terms of present tense, identify the types of errors as well as the sources of the errors. The research is a descriptive study with 11 students participating in the study. The data of the research were collected from 1) the students' writings focusing on students' sentences containing subject-verb agreement errors, and 2) interview to triangulate the data obtained from students' writings. The findings of the research are as follow: 1) Students' subject and verb agreements' errors viewed surface taxonomy's perspective are in the form of misformation, omission, and addition, while viewed from linguistic categorization's perspective, the errors are in the form of improper use of singular/plural nouns placed as the subject, inappropriate use of verbs, and improper use of verbal and nominal sentences in making present tense. The analyzed data also show that students' errors of subject-verb agreement are classified as local errors. 2) The sources of the errors are inter-lingual transfer, intra-lingual transfer, and misleading context of learning. The research reveals that the students are still having difficulties in using correct patterns of subject and verb agreement in their writing using present tense.
\end{abstract}

Keywords: Subject and Verb agreement, error analysis, inter-lingual transfer intra-lingual transfer

\section{BACKGROUND}

Students of higher learning education are expected to be able to use their English to write sentences, paragraphs, or even essays well. The sentences written by the students are expected to be not only grammatically correct but also semantically acceptable. Grammatically correct sentence means that the sentence should follow the rules of the language. Meanwhile, semantically acceptable sentence means that the sentence should be meaningful and far from ambiguity. This requirement is in accordance with their level of education. They are required to do so because as university students, they are exposed with so many academic works to complete. They have to deal with academic-related stuffs, such as, making reports, journals or other publications and later publishing them as well. Therefore, it's clear that being university students requires them to be able to write in grammatically and semantically acceptable sentences.

Moreover, the students of higher learning education are given so many opportunities to experience living or studying abroad. It can be seen from various scholarship programs offered by Indonesia's government. For instance, DIKTI is providing LPDP scholarship for Indonesian students who want to study abroad. Besides, other scholarship programs are offered by the host countries, like Endeavor scholarship from Australia's government, Fulbright scholarship from the United States 
of America and many others. Once the students are interested to apply either an overseas exchange program or a scholarship, they must be able to complete all the documents in English. It means that they must be able to complete the required information in English as an addition to the motivational letters that must be written in English as well in order to pass the documentation selection.

In addition, it's believed that being able to write well in English will contribute to their future career. It's possible to happen because most job vacancy requires the applicants to master English both spoken and written fluently or one of them is preferred as well. Thus, once they have mastered their English well, particularly in writing, it'll ease their way to reach their targeted jobs especially for those who have been exposed to write English well during their study.

It's clearly stated that being able to write well in English using correct patterns of sentences, grammar, punctuation and capitalization also called as mechanics is important for the students of higher education. However, after years of studying English from the primary education level ( $S D$ - elementary school and $S M P$ - junior high school) and secondary education (SMA-senior high school), some even started learning English earlier from early education level (PAUD, TK - Kindergarten), the students still find it difficult in writing their sentences using the correct patterns/rules. They tend to make repeated mistakes dealing with the subject and verb agreement patterns in writing their sentences. Many believe that subject and verb are two basic elements in sentence making process. Thus, once they are able to write Subject that goes along with its verb, it's assumed that the students will be able to write more complex sentences with more complex patterns of writing. However, some students still find it difficult to write sentences correctly in which the subject must agree with the verb. They don't realize that verb must go along with the subject of the sentences or vice versa. This fact leads to the students' unsuccessful mastery of writing.

The similar condition also happens in UMY in which its students face similar problems. They find it difficult in writing the sentences correctly particularly when they have to deal with subject and verb agreement. Based on the frequent observation conducted by the researcher during her classroom practices, some students often found difficulties when it comes to writing activities. They looked confused in writing their sentences. When the researcher came closer to them, they stated that it's somehow confusing to write verb for their sentences, particularly when they have to write in present tense. They questioned the researcher as their teacher whether they have to add 's', 'es' or ' ies' after the verb or leave the verb all alone without adding 's', 'es' or ' ies'. It shows that students may not aware if verb can be changed depending on the subject. As an addition, they argued that when they write nominal sentences, they tend to misuse tobe in writing their sentences. As we know, when it comes to nominal sentence, tobe is needed. There are three forms of tobe in present tense namely is, am and are -is (used for third person singular including he, she, and it), am (used for I) and are (used for third person plural including you, we, and they). Those conditions surely make the students confused.

To support the researcher's claim, here are some sentences taken from the students' writing showing subject and verb agreement errors made by UMY's students in writing their paragraphs, for example: (1) there are some weakness in that place.

(2) there is many people register, (3) I think people of India is very friendly. (3) I very interested with the game (4) We all know if every movie in India use the dance to make that movie interesting. (5) I think India more different. (6) I will learns about the 
traditional dance with the use of traditional clothing because the traditional clothing is very popular in India.

It can be clearly seen that the students' frequent errors in writing are in the form of Subject and Verb agreement. The errors are even found in the simple sentences written by them. The students might not aware that subject must agree with its verb or vice versa. Although it has been studied long before they enter their current level of education, they still face problems with grammar in writing their sentences particularly dealing with its basic element, subject-verb agreement.

With regard of such errors, the relevant theories are presented to analyze the subject and verb agreement errors in their writing. Saville-Troike (2006.p.38) in Fauziati $(2009$, p. 135) define Error analysis as the first approach to the study of SLAsecond language acquisition that includes an internal emphasis on learners' creative ability to construct language. It means that the heavy emphasis of Error analysis is learners' errors and the evidence of how learners' errors could provide an understanding of the underlying processes of second language learning or second language acquisition. To strengthen the idea, Al- Dhubib (2013, p. 10) defines error analysis as a branch of applied linguistics that studies and analyzes errors made by second-language learners. This study is believed as the windows into the language learners' mind by some scholars. In addition, another benefit of conducting error analysis is proposed by Shami (2014, p. 237). He argues that error analysis, offered as an alternative to contrastive analysis, has its value in the classroom research.

After knowing what error analysis is, there must be the distinction between an error and a mistake. According to Applied Linguistics and dictionary of language teaching, a learner makes a mistake when writing or speaking because of lack attention, fatigue, carelessness, or some other aspects of performance. Mistakes can be selfcorrected when linguistic item in a way that a fluent or native speaker of the language regards it as showing faulty or incomplete learning. There are two ways to distinguish between an error and a mistake as stated by Ellis (1997). The first one is by checking the consistency of learners' performance. If they sometime use the correct form and sometimes the wrong one, it is a mistake. However, if they always use it incorrectly, it is then called as an error. The second way is by asking the learners to try to correct their own deviant writings. If they can correct their writings, it means that they are mistakes. However, if they can't revise the mistakes, it means that those are errors.

Errors on Subject and Verb agreement vary. Based on its taxonomies, errors can be classified into several categories. The first categorization is given by James (1998, p. 94-112) in Fauziati (2009, p. 144-146). He categorizes the errors of subject and verb agreement into four types based on its surface taxonomies. This type of taxonomy is based on how learners alter surface structures of the language when they use it incorrectly. According to this taxonomy, errors can be made because of change in surface structure in specific and systematic ways. According to James (1998, p. 94-112) in Fauziati (2009, p. 144-146), there are four types of this taxonomy in which the learners modify target forms in specific and systematic ways (Sompong, 2014, p. 116) namely, omission, addition, misformation, and misordering. Each is presented in the following discussion.

The first type of errors is omission referring to the error characterized by the absence of an item that must appear in a well-formed utterance, for example the missing of verb inflections ( $\mathrm{s}$, es, or ies), verb auxiliaries (is, am, and are). The learners tend to omit grammatical morphemes much more frequently than content words such as in $\mathrm{He}$ 
speak English well ( Fauziati, 2009. P. 145). The second type is addition. It refers to a type of errors that is characterized by the presence of an item that should otherwise not present in a well-formed utterance including the presence of double marking, regulation, and simple addition. E.g. I will learns English. The other one is misformation errors consisting of regulation, archi-forms, and alternating forms, for example the use of he for she, him for he, and etc.n The last one is misordering errors. This type of errors is characterized by the incorrect placement of a morpheme in an utterance. For example, I don't know what is it. (Fauziati, 2009. P. 147).

The second categorization is based on Linguistic category classification proposed by James (1998, pp. 104-113) and Tono (2003, p. 804) in Sompong (2014, p. 115-116). They state that this type of taxonomy specifies errors in terms of linguistic categories as well as in terms of the overall location system of the errors. In broader context, it indicates at what level of language the error is located: in phonology, grammar, lexis, text or discourse and if it is at grammar level, what particular grammatical construction it involves. Some possibilities may include the auxiliary system and passive sentence complements. Having established the level of the error, classifying its class is another thing to do. When the errors show that it's the grammar that cause the errors, the class classifications can be in the form of a noun, verb, adjective, adverb, preposition, conjunction, or determiner.

In addition to the above mentioned types of errors on Subject and Verb agreement, there are two other classifications of errors viewed from the perspective of their effect on the listener or reader namely global errors and local errors ( Dulay, Burt, and Krashen, 1982, p. 189 in Fauziati, 2009. P. 147). Global errors refer to errors that affect overall sentence organization and they significantly hinder the communication making either the listener or the reader understand nothing from the communication. For example, "He amused that movie very much, Not take this bus, we late for school" Meanwhile, the local errors to errors that effect single elements in a sentence and don't hinder the communication significantly. For example, "why we like each other?"

The scholars have claimed several possible reasons causing subject and verb agreement errors. One is proposed by Brown (2000) in Mbau et al (2014, p. 1). He classifies the sources of errors into four sources; inter-lingual transfer, intra-lingual transfer, context of learning, and communication strategies. Inter-lingual transfer mostly happens in the beginning stages of learning other languages. It is because the learners' knowledge about the first language is still strongly set. Thus, there is no doubt if the learners commit many errors in this stage. It is supported by Brown (2000, p. 224) who argues that the early stages of learning a second language are prone to inter-lingual transfer from the native language also called as interference. Unlike inter-lingual transfer, Brown states that intra-lingual transfer refers to the target language as the main factor of errors in learning other language. It means that the factor comes out from the target language. It commonly happens to the students who have already known such knowledge about the target language. Another source of error is caused by misleading explanation from the teacher, wrong presentation of a structure or word in a course book, or maybe because of a pattern that was wrongly memorized but improperly contextualized. It means that the sources of errors in context of learning could be the teachers or the materials. The fourth source of errors is communication strategies referring to the learning style. It means that the teachers should be sure that the techniques they used fit the materials in order to transfer the materials successfully. 
In contrast to Brown's ideas who classifies 4 sources of errors, Shami (2014, P. 324) categorizes the sources of errors into two domains only namely inter-lingual transfer, and intra-lingual transfer. Inter-lingual transfer is a significant source for language learners. He defines inter-lingual errors as the result of language transfer that is caused by the learner's first language. This type of error may occur at different levels such as transfer of phonological, morphological, grammatical lexica- semantic elements of the native language into the target language. The second source of errors is intralingual errors resulting from the target language itself rather than language transfer. For example, learners use two tense markers at the same time in one sentence because they have not fully mastered the target language. When the learners say "Ani is comes here", it is because the subject Ani as the third person requires "is". In short, intra-lingual errors occur because of learners' effort to build up concepts and hypotheses about the target language from their limited experience with it. Although there are two different theories on the sources of errors, each is basically completing one another.

In order to analyze the subject and verb agreement errors made by the students, it's important to consider the principles of Error analysis as proposed by Sidhar (1980:103) in Fauziati ( 2009: 136) consisting of 1) Collecting of data ( either from compositions by the students on a given theme of from examination answers) 2) Identifying the errors ( Labeling with varying degrees of precision depending on the linguistic sophistication brought to bear on the task with respect to the exact nature of deviation. 3) Classifying the types of error ( e.g. error of agreement, articles, verb forms, etc) 4) Giving statement of relative frequency of error types, 5) Identifying the areas of difficulty in the target language, and 6) Analyzing the source of errors.

Similar studies on Error analysis have been conducted by several scholars. One is conducted by Dr.Ibrahim Ali A.Shami entitled University Students' Errors in Using Subject Verb Agreement in Writing. This study focuses on the English Language students' errors while using subject-verb agreement. The research is done to suggest some solutions to the problems faced by the second year students at the college of Education in using subject-verb agreement. This research is intended to find out the errors committed by the learners in subject- verb agreement as well as analyzing these errors, and finding out the sources of those errors and taking pedagogical precautions towards them. The research is systematically written, but unfortunately the finding of the research is too broad and hasn't fully discussed about subject and verb agreement made by the students in writing using present tense. It is therefore believed that there is a need to conduct a research that deeply explores the subject and verb agreement errors made by the students of Universitas Muhammadiyah Yogyakarta in writing using present tense.

The above mentioned phenomenon has urged the researcher to write this article in order to analyze students' Subject and Verb agreement errors in their writing, analyze the sources of the errors and propose some solutions to overcome the problems.

\section{METHOD}

This study is a descriptive study which emerges creative explorations, and serve to organize the findings in order to fit them with explanations and then validate those explanations (Krathwohl,1993) in McLellan and Knupfer (2002, p. 197). In general, the aim of this research is to describe the reality behind phenomenon deeply and descriptively. Descriptive study is conducted to describe a particular phenomenon 
happening in a particular setting by analyzing errors of students' writings. The participants of this research were 11 students of second semester of Universitas Muhamadiyah Yogyakarta majoring in Management. They were selected through purposive sampling. In collecting the data, the researcher used two types of data collections. They were students' writing and interview. The students' writings were in the forms of sentences containing subject and verb agreement errors used to gather the information on the errors made by them. The topic for the writing was decided by the researcher in line with the course syllabus. The students were given a topic to write about the description of certain places for them to visit. They were given 50- 60 minutes to write and then 20 minutes to re check and revise their writings before submitting them to the researcher. The interview, on the other hand, was used to support the findings obtained from the students' writing as well as to triangulate the obtained data from the students' works. After collecting the data, the researcher analyzed the result of interview and analysis on students' subject and verb agreement errors by using descriptive method. In other words, the researcher described the data in through narrative form.

\section{FINDING \& DISCUSSION}

In order to find an insight and concise finding of the study dealing with Subject and Verb agreement made by the students, the researcher used 3 ways in analyzing the errors including 1) surface taxonomy 2) linguistics category taxonomy, and 3) perspective of errors' effect on the listener or reader.

The result of Error Analysis on the students' writings conducted by the researcher indicates that the learners made a number of Subject and Verb agreement errors in writing. To make it clearer, each result of the data analysis is presented in sequence. The first point to discuss is the finding viewed from surface taxonomy perspective. The detailed finding is presented in the following table;

\section{Table 1. An analysis of students' subject and verb agreement errors based on} surface taxonomy

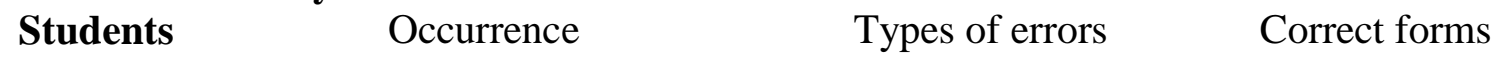

\begin{tabular}{|c|c|c|c|c|}
\hline \multirow[t]{2}{*}{$\begin{array}{l}\text { Student } \\
1\end{array}$} & 1) & $\begin{array}{l}\text { There are many buildings } \\
\text { that has a classical } \\
\text { architecture. }\end{array}$ & Misformation & $\ldots$ have.... \\
\hline & 2) & $\begin{array}{l}\text { It describe about how } \\
\text { strong the culture and } \\
\text { literature of Greece. }\end{array}$ & Omission & It describes.... \\
\hline \multirow[t]{3}{*}{$\begin{array}{l}\text { Student } \\
2\end{array}$} & 1) & $\begin{array}{l}\text { It easier for the muslim } \\
\text { tourists to do prayer. }\end{array}$ & Omission & It is .... \\
\hline & 2) & $\begin{array}{l}\text {...but is balanced with the } \\
\text { beautiful scenery.... }\end{array}$ & Ommision & ...but it is .... \\
\hline & 3) & $\begin{array}{l}\text { Maladewa offer the } \\
\text { beautiful marine tourism. }\end{array}$ & Omission & $\begin{array}{l}\text { Maladewa } \\
\text {..... }\end{array}$ \\
\hline
\end{tabular}




\begin{tabular}{|c|c|c|c|c|}
\hline & 4) & $\begin{array}{l}\text { The beaches has a beautiful } \\
\text { blue sky, green turquoise } \\
\text { water, also the white sand. }\end{array}$ & Misformation & $\begin{array}{l}\text { The beaches have } \\
\ldots . .\end{array}$ \\
\hline & 5) & $\begin{array}{l}\text {...because the resort have a } \\
\text { professional diving staff to } \\
\text { help us. }\end{array}$ & Misformation & $\begin{array}{l}\text {...because the resort } \\
\text { has ..... }\end{array}$ \\
\hline & 6) & $\begin{array}{l}\text { Maldives also have a lot of } \\
\text { mosques, because .... }\end{array}$ & Misformation & $\begin{array}{l}\text { Maldives also has } \\
\ldots .\end{array}$ \\
\hline & 7) & $\begin{array}{l}\text {... and the activities in } 15 \\
\text { minutes before Adzan is } \\
\text { stopped. }\end{array}$ & Misformation & $\begin{array}{l}\ldots \text { the activities in } \\
15 \text { minutes before } \\
\text { Adzan are stopped. }\end{array}$ \\
\hline \multirow[t]{3}{*}{$\begin{array}{l}\text { Student } \\
3\end{array}$} & 1) & $\begin{array}{l}\text { It is has a different culture } \\
\text { with my country, Indonesia. }\end{array}$ & Addition & It has a different .... \\
\hline & 2) & $\begin{array}{l}\text { It is has tall buildings, such } \\
\text { as, pyramid, statue, castle } \\
\text { and ..... }\end{array}$ & Addition & $\begin{array}{l}\text { It has tall buildings } \\
\ldots .\end{array}$ \\
\hline & 3) & $\begin{array}{l}\text { It is has many historical } \\
\text { places and beautiful beach. }\end{array}$ & Addition & $\begin{array}{l}\text { It is has many } \\
\text { historical places..... }\end{array}$ \\
\hline \multirow[t]{3}{*}{$\begin{array}{l}\text { Student } \\
4\end{array}$} & 1) & $\begin{array}{l}\text { I very interested about the } \\
\text { game. }\end{array}$ & Omission & $\begin{array}{l}\text { I am very interested } \\
\ldots .\end{array}$ \\
\hline & 2) & ...because is very beautiful. & Omission & ...because it is .... \\
\hline & 3) & $\begin{array}{l}\text { I think people of India is } \\
\text { very friendly. }\end{array}$ & Misformation & $\begin{array}{l}\text { People of India are } \\
\ldots .\end{array}$ \\
\hline $\begin{array}{l}\text { Student } \\
5\end{array}$ & 1) & $\begin{array}{l}\text {..., so I think Briyani have } \\
\text { a delicious taste }\end{array}$ & Misformation & ... Briyani has .... \\
\hline $\begin{array}{l}\text { Student } \\
6\end{array}$ & & $\begin{array}{l}\text { Everybody know India } \\
\text { because it has many } \\
\text { influences. }\end{array}$ & Omission & $\begin{array}{l}\text { Everybody knows } \\
\ldots .\end{array}$ \\
\hline
\end{tabular}




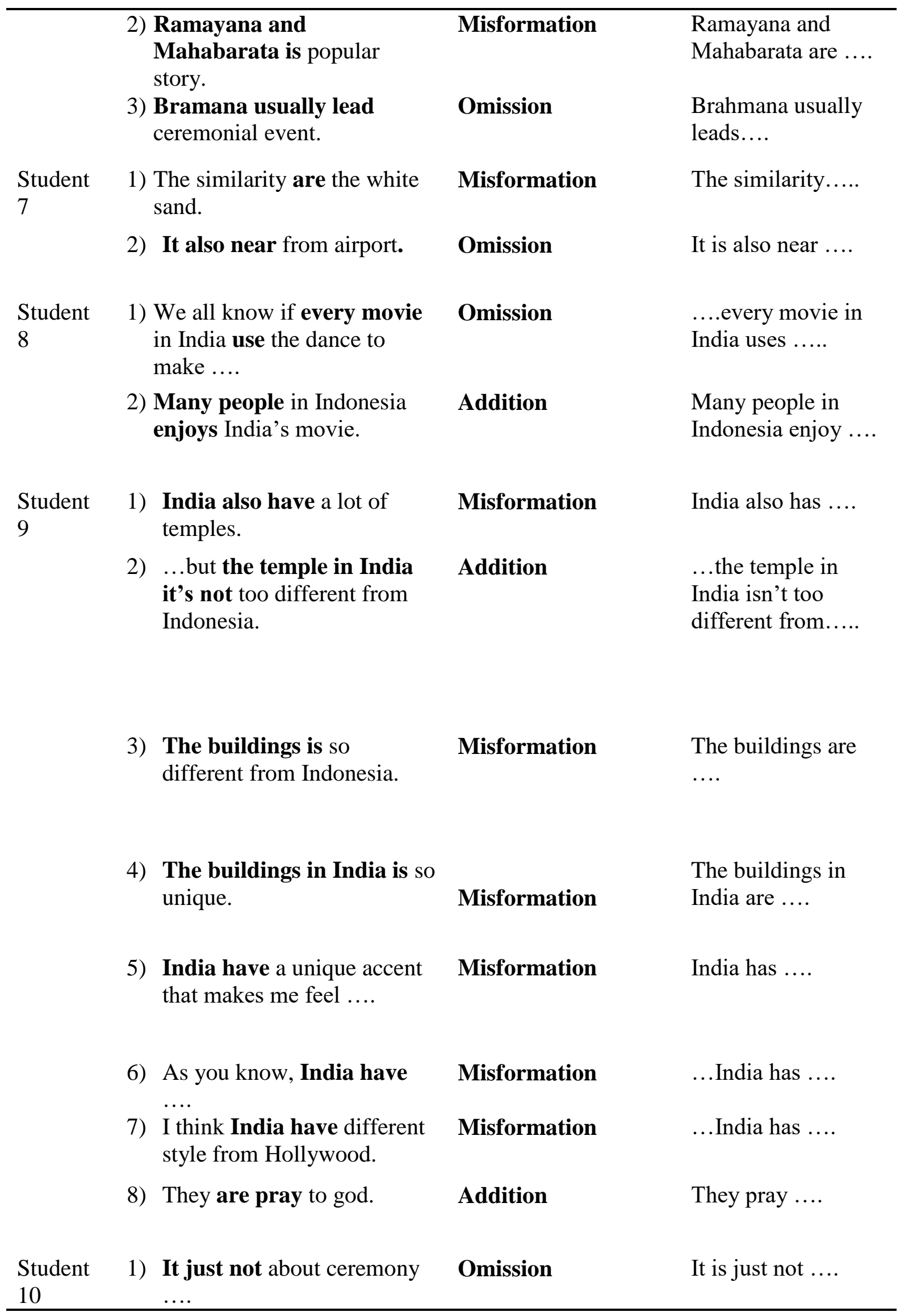


2) I think India more different because ....

Omission

Student 1) Alaska located separately Omission

11 from the main land.

2) The weather in Alaska mostly cold.

3) ...when Ramadhan come, Omission
...India is more ....

Alaska is located

....

The weather in

Alaska is mostly

cold.

...Ramadan comes

The above analysis can be simplified as follow in order to analyze the most frequent errors made by the students found in their writing.

Table 2. Summary of the analysis of frequent subject and verb agreement errors made by the student

\begin{tabular}{|c|c|c|c|c|}
\hline \multirow[b]{3}{*}{ Student 1} & \multicolumn{4}{|c|}{ Frequent Subject and Verb Agreement errors } \\
\hline & Omission & Addition & Misformation & Misordering \\
\hline & 1 & & 1 & \\
\hline Student 2 & 3 & & 4 & \\
\hline Student 3 & & 3 & & \\
\hline Student 4 & 2 & & 1 & \\
\hline Student 5 & & & 1 & \\
\hline Student 6 & 2 & & 1 & \\
\hline Student 7 & 1 & & 1 & \\
\hline Student 8 & 1 & 1 & & \\
\hline Student 9 & 1 & 1 & 6 & \\
\hline Student 10 & 2 & & & \\
\hline Student 11 & 2 & & & \\
\hline Total & 14 & 5 & Students & 0 \\
\hline
\end{tabular}

Since there is no one making this type of errors. After knowing the most frequent errors of Subject and Verb agreement committed the students in writing the paragraph using present tense is misformation, another conclusion can be derived from the data analysis above. It's about another classification of the errors made by the students viewed from the linguistic categorization's perspective. As seen from the result of the analysis viewed from the surface taxonomy's perspective, the frequent linguistic-related errors made by the students deal with improper use of singular/plural nouns placed as the subject, 
inappropriate use of verbs, and improper use of verbal and nominal sentences in making present tense.

At last, as mentioned in the previous discussion, errors can also be classified into global errors and local errors based on their effects on the speaker and listener. All the subject and verb agreement errors made by the students in their writing can be classified as local errors since those errors don't hinder the communication. The researcher, in this case despite of the errors made by the students in their writing, can still understand the messages delivered by the students in their writing. Therefore, those subject and verb agreement errors belong to local errors.

After analysing the types of errors made by the students, identifying the sources of errors is another principle that must be fulfilled to achieve the objective of the study. As mentioned previously, there are 4 sources of errors claimed to be responsible in causing errors in students' writing, namely: inter-lingual transfer, intra-lingual transfer, context of learning, and communication strategies. The data obtained from the in- depth interview indicate that the students' subject and verb errors in writing using present tense are caused by inter-lingual transfer, intra-lingual transfer and context of learning. Each will be presented in the following discussion.

The first source of errors found in this study deals with the inter-lingual transfer in which the mother tongue of the students that led them writing their sentences incorrectly. It's strongly set in their mind making them write their sentences using the same patterns as they write their mother tongue in which it has no additions after its verbs. It can be seen from the following sentences written by the students;

1) We all know if every movie in India use the dance to make ....

2) Many people in Indonesia enjoys India's movie.

3) India also have a lot of temples.

The above sentences show how students' mother tongue interference the process of language transfer. Having 11 students coming from different parts of Indonesia who have different mother tongue such as Javanese, Sudanese, Bahasa Indonesia and others to speak participated in this research makes it possible for the students to make errors. This fact is believed to be the underlying factors leading to the students' errors. This claim is supported by the following interview transcript.

\footnotetext{
"Ada kesulitan tidak ya tadi pas menulis?"

( Were they any difficulties in writing your paragraph?)

SS : “Bingung miss tadi pas nulis verb nya perlu di tambah 's', atau 'es' tidak gitu, terus bingung pakai tobe atau verb gitu"

( We were confused, miss whether we needed to put 's' or ' es' after verb and whether it's also needed to use either tobe or verb)

$R \quad: \quad$ "Iya,, iya,, terus kira-kira yang bikin kalian bingung apa dong?"

( Oh, I see. what made you confused then?)

SS : " Gini miss, kalau di bahasa kita kan gak ada gitu tambah menambah 's' atau 'es', contohnya gini miss, saya makan, paman saya makan, Dina and Hasan makan, tu kan gak perlu nambah2 apapupun, makan ya cukuo makan aja gitu.."
} 
( In our language, we don't need to add 's' or 'es', for example when we say ' makan' or eat in English for different subject, we don't add 's/es' into makans/makanes'.

$R \quad:$ "Ehm, soalnya di bahasa inggris setiap beda subject beda verb yang mengikutinya ya?"

( It's because subject in English requires different pattern of verb, right?"

SS : Heem, miss. Jadi kami bingung e „, kadang mikire agak lama di situ mis..hehehe

(That's true miss, it makes us confused, so sometimes we need more times to write)

The students' responses above show that it's the mother tongue of the students causing students' subject and verb agreement errors in writing. It is possible to happen because the students have fully mastered their mother tongue, so it affects the transfer of the new target language studied by the students.

The second source of errors is intra-lingual transfer in which the target language studied by the students itself that hinders the process of learning. English, in this context, certainly has its own patterns that somehow confusing its learners. The analysed students' errors show that they tend to make sentences with both tobe and verb. For examples;

1. It is has a different culture with my country, Indonesia.

2. It is has tall buildings, such as, pyramid, statue, castle and .....

3. It is has many historical places and beautiful beach.

The three sentences above inform that the use of double tobe and verb ' is and has' because it as the third singular subject requires both "is" and ' has'. Thus, the students assume that they need to write all of them. In fact, they don't necessary to do so because when it's verbal sentence, verb is required. Meanwhile, when it' nominal sentence, the to be is needed.

The above claim is supported by the students' responses in the following interview transcripts.

$\mathrm{R} \quad$ : "Selain kesulitan tadi, ada kesulitan lagi ga yang bikin kalian susah nulis?"

( Were there any other difficulties?)

SS : "Ini miss, bingung kapan harus pake tobe, has/have".

( confused on when we have to use tobe, has/have, miss)

$\mathrm{R} \quad$ : "Bingungin banget ya, emm, terus akhirnya tadi kalian nulisnya gimana, pakai tobe atau verb, atau gimana”?

( Very confusing, isn't it? Then how did you finally write your sentences? Were you using tobe, verb, or...)

SS : "kayaknya tadi sih bener miss, hehe, tapi ada beberapa yang saya tulis pakai tobe dan verb, habis saya bingung."

( I thought we did it well, miss, but there were some that written using both to be and verb)

The last source of errors found in this study is context of learning. There were misleading inputs that students obtained during their learning. They consider those inputs as the correct models to learn. However, in fact, they are the responsible causes of the errors. This is supported by the student's response in the following interview transcript.

Miss, dulu guru saya SMP pernah bilang 'I happy because you get good 
score', tu gak pakai to be miss.. Jadi saya ikut-ikut itu..hehehe ( Miss, my junior high school's teacher once said 'I happy because you get good score', he didn't put to be miss, so im copying her ..(laughing)

After analyzing the types and sources of students' subject and verb agreement errors, some solutions are proposed by the researcher to overcome the problems. They are presented as follow:

1. After giving the patterns, more examples on subject and verb agreement must be given to the students as well.

2. The students should practice intensively the patterns explained by the teacher. By doing so, they'll able to internalize their knowledge in practice.

3. The teacher must give the students homework focusing on the diverse types of subjects and verbs.

4. Another way that can be done in reducing errors made by the students in subject verb agreement is by getting them to check each other's work. This activity will lead them in an active search for errors. Another benefit of conducting this activity is letting the students to use their English maximally in classroom practices since English is used for a means of communication while discussing these errors with their friends.

\section{CONCLUSION}

This study proves that the students still find it difficult in using subject and verb correctly to write paragraphs in present tense. There are three types of errors experienced by the students namely misformation, omission and addition. Those errors are caused by the inter-lingual transfer, intra-lingual transfer, and misleading inputs. In order to overcome the problems, the teacher needs to employ breakthrough strategy/ approach in teaching her students. The activities must enable the students to improve their awareness of subject and verb agreement to write paragraphs in present tense. It's hoped that by doing this, the students can accelerate their writing so that their English will function well.

\section{REFERENCES}

Al-Dubib, Dalal A. ( 2013). Error Analysis of Subject-Verb Agreement in the Writing of EFL Saudi Female Students: A Corpus-Based Study. Al-Imam Mohammad Ibn Saud Islamic University: Saudi

Brown, H. D. (2000). Principles of language learning and teaching. Englewood Cliffs, NJ: Prentice Hall.

Ellis, R. 1986. Understanding second language acquisition. Oxford: Oxford University Press.

Fauziati, Endang. (2009). Readings on Applied Linguistics: A Handbook for Language Teachers and Teacher Researchers. Surakarta; Era Pustaka.

Mbau, Anitha Thalib et al. ( 2014). An analysis on the subject-verb agreement errors in writing paragraph made by the second semester stusents of English department. e-Journal of English Language Teaching Society (ELTS) Vol. 2 No. 22014 ISSN 2331-1841. 
McLellan, Hillary and Knupfer, Nancy N. Descriptive research methodologies.McLellan Wyatt Journal of Kansas State University.Retrieved on October 2, 2015.

Shami, Ibrahim Ali A. (2014). University Students' Errors in Using Subject Verb Agreement in Writing. Riyard; Al-Nasser University.

Sompong, Monnipha (2014). Error Analysis. Language Institute; Thammasat University 